\title{
Odonata of Yap, Western Caroline Islands, Micronesia ${ }^{1}$
}

\author{
Donald W. Buden ${ }^{2,4}$ and Dennis R. Paulson ${ }^{3}$
}

\begin{abstract}
Fifteen species of Odonata are recorded from Yap, Micronesia-two Zygoptera and 13 Anisoptera. None is endemic to Yap. Hemicordulia lulico occurs elsewhere only in Palau, whereas most of the other species are widespread in the western Pacific and Indo-Australian regions. Macrodiplax cora and Tramea loewi, both recorded by Lieftinck in 1962, were the only species not encountered during this study; Tramea loewi remains known in Micronesia only from a single male collected in Yap by R. J. Goss in 1950. Six of the breeding species in Yap that are widespread in Indo-Australia occur no farther east in the Caroline Islands except possibly as unusual extralimital records in the cases of Agriocnemis femina and Neurothemis terminata; the four other species reaching only as far east as Yap are Anaciaescbna jaspidea, Agrionoptera insignis, Orthetrum serapia, and Rbyothemis phyllis. Orthetrum serapia is reported from Micronesia for the first time, although a very old single specimen record of $O$. sabina from Tobi Island may possibly pertain to $O$. serapia. The odonate fauna of the outer islands of Yap State is poorly known; only six species have been recorded from among four of the 15 island groups. In addition, Tramea transmarina euryale rather than T. t. propinqua was found to be the subspecies occurring in the Chuuk Islands, contrary to earlier publications.
\end{abstract}

This STUDY is the sixth in a series of articles by the authors on the status of Odonata populations in Micronesia, which were last reviewed by Lieftinck (1962). Our previous surveys included the islands of Chuuk (Buden and Paulson 2004), Pohnpei (Paulson 2003, Paulson and Buden 2003), northern Pohnpei State atolls (Buden 2004), and Kosrae (Buden and Paulson 2003). The study reported here is based largely on new material collected by D.W.B. on Yap during mid-June to early August 2005.

\footnotetext{
${ }^{1}$ Manuscript accepted 28 June 2006.

2 Corresponding author.

${ }^{3}$ Division of Natural Sciences and Mathematics, College of Micronesia-FSM, P.O. Box 159, Kolonia, Pohnpei, Federated States of Micronesia 96941 (e-mail: don_buden@comfsm.fm).

${ }^{4}$ Slater Museum of Natural History, University of Puget Sound, Tacoma, Washington 98416 (e-mail: dennispaulson@comcast.net).
}

Pacific Science (2007), vol. 61, no. 2:267-277

(C) 2007 by University of Hawai'i Press

All rights reserved

\section{Previous Studies on Yap}

Lieftinck (1962) recorded two species of $\mathrm{Zy}$ goptera (damselflies) and 11 species of Anisoptera (dragonflies) on Yap and described Agrionoptera insignis yapensis as an endemic subspecies. Many of the specimens that Lieftinck examined were collected by Richard J. Goss during July-August 1950. One A. $i$. yapensis reported as collected by Goss in November 1952 was probably misdated or misattributed. No other Goss specimens mentioned by Lieftinck have that date, and Gressitt (1954) mentioned only 1950 as the year during which Goss visited Yap. Furthermore, Dinsmore and Aronson (1997:353) stated that Goss “earned his bachelor's from Harvard [in 1948], stayed on under the tutelage of Professor Frank Carpenter (and spent one memorable summer as an entomologist on the Pacific island of Yap) to earn master's (1951) and doctoral degrees (1952)." But there is no indication that he revisited Yap after 1950.

Lieftinck (1962) also examined specimens of odonates collected by J. L. Gressitt and N. L. H. Krauss during July 1951, August 1952, and October-December 1952, and an 
unstated number of Agriocnemis femina collected by J. W. Beardsley during MarchApril 1954. Lieftinck (1962) also included records obtained by Japanese collectors during the 1930s, and which were previously reviewed by Asahina (1940).

More recent information on the Odonata of Yap obtained since Lieftinck's (1962) review is almost completely lacking. Schreiner and Nafus (1989) recorded larvae of nine species of odonates in a survey of aquatic insects during 15-28 September 1988. Tsuda et al. (2003) reported on the entomological results of the 2001 Yap Research Expedition by the Kagoshima University Research Center for the Pacific Islands. Their report mentions six species of odonates collected on Ulithi Atoll, but they did not list them and did not mention any collections from Yap proper. However, K. Tsuda (pers. comm.) provided an unpublished list of 12 specimens among seven species (plus one identified only as Neurothemis sp.) collected on Yap proper during 17-29 October.

\section{Study Area}

Yap proper (= Yap main islands, the geographic focus of this study) consists of four closely juxtaposed islands surrounded by a fringing reef in the West-central Pacific Ocean at $9^{\circ} 33^{\prime} \mathrm{N}$ and $138^{\circ} 09^{\prime} \mathrm{E}$ (Figure 1). Excluding the reef area, Yap is approximately $24 \mathrm{~km}$ long, 5-10 km wide, and $98 \mathrm{~km}^{2}$; the highest elevation is $178 \mathrm{~m}$ at Mt. Taabiywol. Yap is also the name of the largest island $\left(55 \mathrm{~km}^{2}\right)$ in the group; the three others are Rumung $\left(4 \mathrm{~km}^{2}\right)$, Maap $\left(10.6 \mathrm{~km}^{2}\right)$, and Gagil-Tamil $\left(28 \mathrm{~km}^{2}\right)$. The 6-m-wide and ca. 300-m-long canal separating Yap Island from Gagil-Tamil was constructed in 1901 during the German administration to assist access to the northern villages (Adams 1997).

The name Yap also applies to Yap State, which includes Yap proper along with 15 atolls and low coral islands that are sparsely distributed over an area that extends to 1,000 $\mathrm{km}$ east of the main islands. Yap, Chuuk, Pohnpei, and Kosrae States make up the Federated States of Micronesia (FSM), which, together with the Republic of Palau to the west, make up the Caroline Islands (Figure
1). Palau and Yap proper are on the eastern edge of the Philippine Plate and consist largely of metamorphic rock and andesitic volcanics, whereas the other Caroline Islands (including outer islands of Yap with the exception of Ngulu Atoll midway between Yap and Palau) are on the Pacific Plate and are oceanic volcanics or atolls on descending volcanic cones (Munetomo et al. 2001, Descantes 2005).

The mean annual temperature in Yap is $27^{\circ} \mathrm{C}$, and the monthly mean varies only by approximately $1{ }^{\circ} \mathrm{C}$. Mean annual rainfall is ca. $300 \mathrm{~cm} / \mathrm{yr}$. The wet season is July to October $(33 \mathrm{~cm} / \mathrm{month})$ at which time the prevailing winds are southwesterly, and the dry season $(18 \mathrm{~cm} / \mathrm{month})$ is November to June when northeast trade winds prevail (Adams 1997, Dodson and Intoh 1999). "Typhoons are fairly uncommon, with only three per year passing within 120 nautical miles, most often in May, June, and November" (Adams 1997:2).

The interior of Yap proper is hilly and covered with a patchwork of forest (mainly in the ravines) and savanna (mainly on the central plateau and hilltops). Much of the land has been modified by centuries of human occupation and managed as agroforest, where the native vegetation is partially cleared for cultivation (Falanruw et al. 1987, Mueller-Dombois and Fosberg 1998). Dodson and Intoh (1999) suggested that major forest destruction, probably anthropogenic in origin, began about 3,000 yr ago, and that the now extensive savanna may be an artifact of human impact on vegetation and soil. The 2000 census recorded 5,838 people living on Yap (Division of Statistics, FSM National Government, 2004), but "as many as 40,000 to 50,000 people may have lived on Yap proper at the beginning of the 19th century ... [and] stories of this time tell of some hardship and hunger, the possible consequence of overpopulation" (Merlin et al. 1996:9).

The aquatic habitats of Yap, and potential breeding sites of odonates, include streams, ponds, marshes, seepage areas, mangroves, drainage ditches, roadside rain puddles, taro patches, and phytotelmata. Streams are abundant, but few are perennial; all of those on 


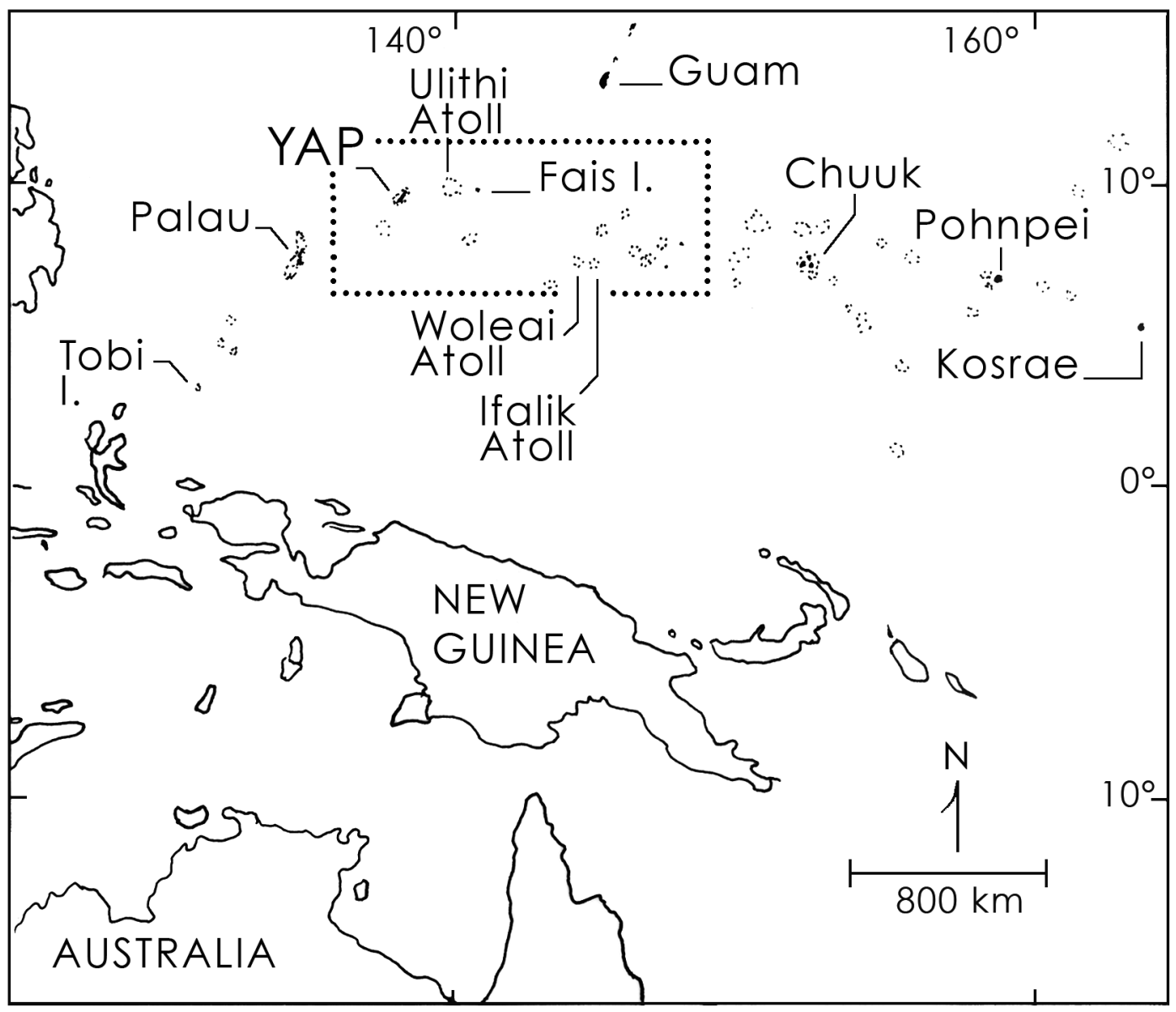

FIgURE 1. Location map of Yap State islands (dotted rectangle) and surrounding western Pacific islands.

Yap Island are dry from a few days to several months during the year (van der Brug 1983). Most streams are shaded by forest canopy for much of their length, whereas ponds are usually well exposed to sunlight and surrounded by open savanna vegetation (Lobban 1989; pers. obs., this study). Brackish-water swamps dominated by Nypa palms are common in the lowlands.

\section{MATERIALS AND METHODS}

A total of 253 adults of 13 species of odonates was collected throughout the main islands of Yap proper by D.W.B. during 12
June-4 August 2005. Specimens were netted during walks along roads and footpaths through a variety of habitats on all four islands. Specimens were dried in envelopes and deposited in the D. R. Paulson collection. Terms of abundance relate to encounter rates during this survey unless specified otherwise: very common (seen daily in large numbers, often several hundred to over 1,000 per day), common (at least 25 encounters on most days), fairly common (approximately 10-25 encounters on most days), uncommon (usually no more than 10 sightings per day and unobserved on some days), scarce (usually no more than five encounters in a single day and not encountered on most days). 
RESULTS

Suborder Zygoptera

Family Coenagrionidae

Agriocnemis femina (Brauer)

The nominate subspecies of $A$. femina ranges widely from Asia to Australia and has been recorded in Micronesia from the southern Mariana Islands, Palau, and Yap (Lieftinck 1962, Steinmann 1997). Lieftinck (1962:44) recorded it in Yap from "many various localities," and Shreiner and Nafus (1989) recorded larvae in many different aquatic habitats. This species was very local in distribution during the study reported here but usually common where it occurred. It was most frequently encountered in grassy, weedy areas adjacent to shaded forest streams.

\section{Ischnura aurora (Brauer)}

This species ranges widely from India and Southeast Asia southward and eastward to Australia, New Zealand, and Polynesia (Steinmann 1997). Lieftinck (1962) recorded it on all major island groups in Micronesia except for Palau. In Yap, Schreiner and Nafus (1989) recorded larvae of I. aurora in many streams and still waters, often with, but usually in smaller numbers than, A. femina. Ischnura aurora was scarce during the JuneAugust 2005 survey. One male was collected in grasses and weeds along the shore of Gitaem Reservoir, and two other males were collected at a water-filled ditch at the College of Micronesia campus, all during 13-23 June; no others were recorded.

\section{Suborder Anisoptera \\ Family Aeshnidae}

Anaciaeschna jaspidea (Burmeister)

This species occurs widely from India and Southeast Asia southward to Australia; Lieftinck (1962) recorded it in Micronesia on Guam, Palau, and Yap. His Yap material consisted of four males and a female collected by R. J. Goss during July-August 1950. Anaciaeschna jaspidea was uncommon to fairly common on Yap during the survey reported here. It was frequently encountered in upland savannas, often being flushed from trailside grasses, and it was often seen flying in wide circular or elliptical patterns above the surface of roads, especially shortly after sunrise.

Anax guttatus (Burmeister)

Lieftinck (1962) recorded Anax guttatus from many islands in Micronesia, but not Yap, the omission of which may have been an oversight. The Bishop Museum has an early instar larva (15.0 mm long) collected in Yap by R. J. Goss during July-August 1950 that is labeled "guttatus (Burm) det. M. A. Lieftinck 1952." It is mounted on a pin in a specimen box that bears the label Anax guttatus and contains 18 other small (ca. 5-10 mm long) larvae also collected by Goss in Yap in 1950. But these other specimens lack determination labels and appear to include species other than $A$. guttatus. Schreiner and Nafus (1989:22) did not mention the Bishop Museum specimen, but they recorded "[two] larval forms (naids) of the genus Anax, not previously reported from Yap ... in two locations." The specimens were not identified as to species explicitly in that account, though Schreiner and Nafus (1989:29) went on to say that $A$. guttatus "occurs widely in the Carolines, and may have been missed in previous collections in Yap."

Only six $A$. guttatus were observed during the survey reported here (summer 2005); one was collected. Their large size and blue coloration on the anterodorsal part of the abdomen readily distinguished them in the field from Anaciaeschna jaspidea, the only other aeshnid known to occur in the FSM. One of the six specimens was patrolling over a waterfilled but otherwise empty taro pit at the southern end of Yap Island on 10 July. The five others were seen at the northern end of the island on 2 August-one over a weedchoked roadside pool and four together (two in tandem) over open water in a Nypa palm swamp.

\section{Family Cordulitdae}

\section{Hemicordulia lulico Asahina}

The genus Hemicordulia is represented in the Caroline Islands by three endemic species described by Asahina (1940)-H. erico on Kosrae, $H$. haluco on Pohnpei, and $H$. lulico in Palau and Yap. Few specimens are known 
from Yap, whence Asahina (1940) examined six males and one female collected during 22 October-11 November 1939; Lieftinck (1962) examined one of the paratypes. Schreiner and Nafus (1989:22) apparently did not encounter this species during their survey in September 1988 because they stated, "a Corduliidae species reported as being in Yap was not found." The Kagoshima University Expedition collected one specimen on Yap Island on 18 October 2001.

Hemicordulia lulico was much more numerous during the study reported here than is indicated by the scanty past records. It was frequently seen flying (and seldom perched) along roadsides and wherever there were open spaces with at least scattered trees and shrubs. It was found occasionally in forest but usually in small, open patches and not under closed canopy. Small groups of 5-15 were often seen flying in roughly circular routes approximately $2-4 \mathrm{~m}$ above the ground within areas several meters in diameter, especially during late afternoons on calm, windless days. All six specimens collected from one such aggregation on 22 June were males, and 25 of the $30 \mathrm{H}$. lulico collected during the course of this study were males. A male and female were collected in tandem perched on the frond of a young coconut tree at the edge of a Nypa palm swamp on 17 July 2005.

\section{Family Libellulidae}

\section{Agrionoptera insignis (Rambur)}

Lieftinck (1962) described Agrionoptera insignis yapensis as a subspecies endemic to Yap; he examined a series of 17 males and $21 \mathrm{fe}-$ males collected between July and December, all during the early 1950s. Although Davies and Tobin (1985) and Steinmann (1997) treated "yapensis" as a full species, with no rationale for doing so, examination of a series of $A$. insignis from Malaysia, Papua New Guinea, Australia, and the Philippines convinced us that "yapensis" does not deserve species status. In fact, we found no differences worthy of nomenclatorial recognition between the series from Yap and smaller series from the southern Philippines and Borneo in D.R.P.'s collection. Because there has been no modern revision of the plethora of names that have been applied to the insignis complex (Lieftinck 1962), we prefer to use only the species name for the Yap population.

No more than five were observed during the early part of the study reported here (11-25 June), but by mid-July the species was frequently encountered perched on the tips of twigs of shrubs and on tendrils of vines, particularly along secondary roads bordering swampy, marshy areas, including taro patches; 78 were counted in $90 \mathrm{~min}(52 / \mathrm{hr})$ along approximately $3.0 \mathrm{~km}$ of unpaved road in the southern part of Yap Island on 23 July 2005.

\section{Diplacodes bipunctata (Brauer)}

Lieftinck (1962) considered D. bipunctata one of the most dominant dragonflies in Micronesia. It was common to very common on Yap during the study reported here and was most frequently encountered in open, sparsely vegetated areas. Many pairs were observed in copula and many females were ovipositing alone or in tandem with males. Oviposition was usually on the surface of shallow puddles, including water-filled ruts on gravel roads, and in drainage ditches and taro patches.

\section{Macrodiplax cora (Brauer)}

This species occurs from India and the Indian Ocean islands across Southeast Asia southward and eastward to Australia, New Guinea, and Samoa (Steinmann 1997); Lieftinck (1962) recorded it in Micronesia from the Mariana Islands, Palau, and Yap, with the Yap record apparently based on a single male collected by R. J. Goss, July-August 1950. This specimen remained the only record for the FSM until Buden and Paulson (2004) recorded $M$. cora as the most common odonate on Houk Island (= Pulusuk Atoll) in western Chuuk State in December 2002. None was encountered on Yap during the study reported here.

\section{Neurothemis terminata Ris}

This species ranges from Malaysia southward and eastward to the Lesser Sunda Islands, the Philippines, and western Micronesia in Palau and Yap; Micronesian popula- 
tions fall within the range of the nominate subspecies (Lieftinck 1962, Steinmann 1997). Lieftinck (1962:79) did not list specific records from Yap but referred to "many ... from various localities." Neurotbemis terminata was very common and the most abundant odonate on Yap during the study reported here. It was most common in wet, marshy, grassy areas; 80 were counted in five min $(960 / \mathrm{hr})$ along approximately $100 \mathrm{~m}$ of trail through tall, dense grasses at the southern end of Yap on 30 July, and similar densities were encountered widely throughout the island. They would flush from the grasses and weeds only to fly a short distance and resettle away from the observer. This was the odonate most likely to be seen during cloudy, windy, rainy days but possibly more as a reflection of its overall larger numbers than of any greater tolerance or indifference to inclement weather. It was not usually encountered in closed-canopy forest but occurred in forest openings and edges. Several pairs were observed in copula in taro patches and weedy ponds, and a female collected on 1 August released eggs when captured.

Among 39 specimens in the genus Neurothemis collected by the Kagoshima University Expedition, Katsua Tsuda (pers. comm.: e-mail, April 2005) listed four N. t. terminata collected on Yap proper and 28 on Ulithi Atoll. Six others from Ulithi and one from Yap were identified only as Neurothemis sp. and said to be larger than N. t. terminata and thus similar to N. ramburi. All specimens collected during the study reported here were clearly $N$. terminata. Lieftinck (1962) found three of 28 females $(10.7 \%)$ to be andromorphs; of the 19 collected during the study reported here, two $(10.5 \%)$ were andromorphs. Lieftinck (1962) wrote that $40 \%$ of females had the apices of their wings brown inward to well proximal of the pterostigma. In contrast, none of the females collected in 2005 was so colored. No explanation for this difference comes to mind.

\section{Orthetrum serapia Watson}

This species was first described by Watson (1984) and is distinguished from the morphologically very similar $O$. sabina largely by dif- ferences in color pattern on the fourth abdominal tergite. It has not been previously reported in Micronesia. Watson (1984) and Watson et al. (1991) recorded O. serapia from Indonesia and the Philippines southward and eastward to New Guinea, Australia, the Bismarck Archipelago, the Solomon Islands, Samoa, and Fiji. It overlaps broadly with $O$. sabina in the Indo-Australian region (Watson et al. 1991). Until recently, the genus was known in Micronesia only from a single male "O. sabina" collected on Tobi (Southwest Palau Islands), the westernmost island in $\mathrm{Mi}$ cronesia (Lieftinck 1962). Whether this specimen is indeed $O$. sabina or whether it is an example of the more recently described $O$. serapia is unknown. Orthetrum sabina has been recorded recently on Guam (Inoue et al. 1999), and we have examined photos taken there and confirmed identification as $O$. $s a$ bina.

Orthetrum serapia was widespread and common in lowland, aquatic habitats throughout Yap during the study reported here. It was frequently encountered in roadside drainage ditches and pools of standing water in open, sunny areas. Single individuals were often seen patrolling slowly just a few centimeters above the surface of the water or alighting on the tips of grass blades or other low, emergent or shoreline vegetation. At least five or six females were observed ovipositing on the surface of the water, and as many pairs each were observed in tandem or in copula. Thirty-four of the 38 specimens collected were males, and only one individual (a female) was observed (and collected) in the uplands. It was in dense grasses growing in a disused roadbed passing through secondary woodland on Mt. Taabiywol at an elevation of approximately $100 \mathrm{~m}$.

In view of the moderately large size of this species and its tendency to fly low and conspicuously in open, exposed habitats, it is unlikely to have been overlooked by either the Japanese odonatologists of the 1930s or by R. J. Goss during the summer of 1950 . In all probability it arrived and became established on Yap sometime after 1950, whether by human assistance or by independent dispersal is unknown. It is interesting that it was not re- 
corded by entomologists from the University of Guam in 1988 or those from Kagoshima University in 2001. But both of those survey teams were on Yap for a relatively short time and did not focus specifically on Odonata. Also, though it is not known if O. serapia exhibits seasonality on Yap, the Guam entomologists were there in September and the Kagoshima Expedition was in October, whereas the survey reported here was in mid-June to early August.

\section{Pantala flavescens (Fabricius)}

This nearly cosmopolitan species was previously collected on Yap by Goss during July-August 1950 and by Gressitt and Krause during October-December 1952 (Lieftinck 1962). None was reported on Yap proper by Schreiner and Nafus (1989) during their September 1988 survey or by the Kagoshima University Expedition in October 2001 (K. Tsuda, pers. comm.). It was scarce on Yap during the study reported here; fewer than 10 were seen during mid-June to early August, all of them patrolling over roads in coastal settlements or in open, sparsely vegetated areas.

\section{Rhyothemis phyllis (Sulzer)}

The 12 subspecies of $R$. phyllis recognized by Steinmann (1997) together range from India southward and eastward to the Philippines, Indonesia, New Guinea, Australia, western Micronesia, the Solomon Islands, and Fiji. The Micronesian populations (recorded on Guam, Palau, and Yap) comprise an endemic subspecies, $R$. p. vitellina Brauer. Rhyothemis phyllis was uncommon to locally common on Yap during the study reported here. It was usually found in the vicinity of open water and less frequently in upland savannas.

\section{Tholymis tillarga (Fabricius)}

Tholymis tillarga occurs widely from Africa and Madagascar to southern Asia southward to Australia and Oceania (Steinmann 1997). It was fairly common on Yap throughout the study period and was most frequently encountered in the vicinity of small ponds and swampy areas with at least patches of open water, and usually in late afternoon and early evening. During the day it was often flushed from grasses and weeds and was readily identified by its erratic flight.

\section{Tramea loewi Brauer}

This species ranges from the Lesser Sunda Islands and the Moluccas southward to New Guinea, Australia, and Yap (Lieftinck 1962); a male collected by Goss on Yap during July-August 1950 is the only record for Micronesia. The absence of records from elsewhere in Oceania suggests that the specimen from Yap represents an unusual extralimital occurrence. The nearest known resident populations are in New Guinea, approximately $1,100 \mathrm{~km}$ to the south.

\section{Tramea transmarina euryale Selys}

Lieftinck (1962) recognized two subspecies of T. transmarina in Micronesia-T. t. propinqua Lieftinck in the east (Chuuk, Pohnpei, Kosrae, the Marshall Islands, and Kiribati), and T. t. euryale Selys in the west (Palau, Yap, and the Mariana Islands), distinguished primarily by the width of the dark marking at the hind wing base; the species ranges from Japan southward to the Indo-Australian region and Oceania. With the series of $T$. transmarina now available to us from Micronesia, we compared specimens from each island group. Indeed, those from Yap are the western form euryale (type locality, North Celebes = Sulawesi); the basal hind wing marking extends out to the cubito-anal crossvein. Those from Ant Atoll, Pohnpei, and Kosrae are the eastern form propinqua (type locality, North New Guinea). Contrary to Lieftinck's (1962) conclusion, which we had not questioned in an earlier paper (Buden and Paulson 2004), those from Chuuk and Satawan Atoll are clearly T. t. euryale in having narrow hind wing markings.

This was one of the most common dragonflies on Yap during the study reported here and the one most characteristic of the upland savanna areas on hilltop summits and ridge crests. It was often encountered in small groups of 2-10 and often seen flying in loose circular routes $2-5 \mathrm{~m}$ above the ground on roadsides. Many were seen in tandem and in 
copula, and females were observed ovipositing in water-filled ditches and taro patches. Six pairs were observed in tandem in savanna grassland west of the airport on 16 July.

\section{DISCUSSION}

Of the 15 species of Odonata recorded in Yap, 14 are widespread in the Indo-Australian region and western Pacific islands, and in many cases well beyond. Ten of the 13 genera represented on Yap are among those listed by Rowe (2004) as including species capable of considerable transoceanic movement and being widely dispersed among Pacific Ocean islands. No species is endemic to Yap, but Hemicordulia lulico occurs elsewhere only in Palau. Of all the anisopteran genera of Micronesia, Hemicordulia has been the most likely to speciate in situ.

Lieftinck (1962) and Paulson and Buden (2003) commented on the general reduction in the number of species of odonates from west to east in the Caroline Islands being attributed to area/distance effects as predicted by the theory of island biogeography. The one major perturbation stems from the unusual radiation of six endemic, sympatric species of Teinobasis damselflies in the riverine and montane habitats of Pohnpei; Palau and Chuuk each have one species and Yap and Kosrae have none. The low relief of Yap (178 m maximum elevation) together with the paucity of perennial streams may at least in part explain the absence of Teinobasis there.

The largest number of odonate species occurred in freshwater and brackish-water estuarine swamps; all 13 anisopteran species were encountered in this habitat type. Among habitats with the fewest number of odonate species were forest streams, where pockets of Agriocnemis femina were occasionally encountered and where a few other species (mainly Agrionopteris insignis, Hemicordulia lulico, and Tholymis tillarga) were seen from time to time, mainly where sunlight filtered through the canopy. Few odonates were observed in mangroves, and they were mainly at the inland edge, where $A$. insignis was occasionally fairly common. Phytotelmata were not completely surveyed, but an examination of ap- proximately 30 pitchers of the pitcher plant Nepenthes mirabilis, which occurs in Yap but nowhere else in the FSM, revealed no odonate larvae, and none was reported from any of the pitchers (or in any other phytotelmata or "container" habitats) examined by Schreiner and Nafus (1989). The extensive savanna grasslands with scattered pandanus trees had relatively few species of odonates, but Tramea transmarina was almost always present, especially on hilltops, and Anaciaeschna jaspidea and Hemicordulia lulico were fairly common.

Six species of Odonata apparently breed in the Caroline Islands only as far east as Yap or one of its outer islands-Agriocnemis femina, Anaciaeschna jaspidea, Agrionoptera insignis, Neurothemis terminata, Orthetrum serapia, and Rhyothemis phyllis. Tramea loewi, known only from one old specimen collected on Yap, is considered a vagrant to Micronesia and is omitted from this list. Two unusual "distribution records" from among these species bear mention in the context of the biogeography of Caroline Islands Odonata. The Bishop Museum has a specimen of Agriocnemis femina labeled as collected on Ponape [= Pohnpei] by Beardsley on 7 November 1953, and a specimen of Neurothemis terminata labeled as collected on Mt. Fenkol, Kusai I. [= Kosrae] by Z. Ono on 20 January 1936. Neither of these "records" is mentioned by Lieftinck (1962), who worked extensively with Bishop Museum collections. Lieftinck (1962:44) stated, "the absence of $A$. femina femina from the eastern Caroline Islands and the eastern archipelagoes is worthy of note and hard to explain," and, regarding N. terminata, Lieftinck (1962:79) stated, "this species has reached Fais Island [Yap State], but apparently does not extend farther east." Neurothemis terminata was not encountered in Kosrae during a recent survey (Buden and Paulson 2003), and neither N. terminata nor A. femina was seen on Pohnpei (Paulson and Buden 2003) or on Chuuk (Buden and Paulson 2004), which is much closer to Yap. At best, these two specimens, if correctly labeled and identified, appear to be rare and unusual, incidental extralimital records and not an indication of established populations. The lack 
TABLE 1

List of Odonata Collected on Yap Proper during June-August 2005, with Sources of Records for the Outer Islands of Yap State

\begin{tabular}{|c|c|c|c|c|c|}
\hline \multirow[b]{2}{*}{ Species } & \multirow[b]{2}{*}{ Yap Proper } & \multicolumn{4}{|c|}{ Yap Outer Islands } \\
\hline & & Ulithi Atoll $^{a}$ & Fais Island ${ }^{b}$ & Woleai Atoll & Ifalik Atoll \\
\hline Agriocnemis femina (Brauer) & $15 \hat{\jmath} / 6$ 우 & & & & \\
\hline Ischnura aurora (Brauer) & & & & & \\
\hline Anaciaeschna jaspidea (Burmeister) & $61 / 39$ & & & & \\
\hline Anax guttatus (Burmeister) & $1 \hat{\sigma}^{\hat{\gamma}}$ & & & $1 \delta^{c}$ & 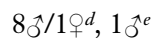 \\
\hline Hemicordulia lulico Asahina & $25 \pi / 5$ 앙 & & & & \\
\hline Agrionoptera insignis (Rambur) & $16 \hat{3} / 16$ ? & & & & \\
\hline Diplacodes bipunctata (Brauer) & $8 \pi / 69$ & 5 & & & $+^{d}, 1$ e $e$ \\
\hline Macrodiplax cora (Brauer) & $0 f^{\prime+}$ & & & & \\
\hline Neurothemis terminata Ris & $18 \hat{\sigma} / 20$ + & $34 g$ & $+^{b}$ & & \\
\hline Orthetrum serapia Watson ${ }^{i}$ & $34 \pi / 49$ & & & & \\
\hline Pantala flavescens (Fabricius) & $5 \leqslant / 19$ & 2 & + & & $+^{d}$ \\
\hline Rhyothemis phyllis (Sulzer) & $7 \hat{\delta} / 5+$ & 1 & & & \\
\hline Tholymis tillarga (Fabricius) & $7 \delta / 10$ & & & & $+^{d}, 1 \jmath^{e}$ \\
\hline Tramea loewi Brauer & $0^{j}$ & & & & \\
\hline Tramea transmarina Brauer & $23 \hat{\jmath} / 17 q$ & & & & \\
\hline
\end{tabular}

+ , Recorded but number and sex of specimens unstated.

${ }^{a}$ Based on unpublished records of the Kagoshima University 2001 Expedition to Yap and Ulithi (Katsuo Tsuda, pers. comm.).

${ }^{b}$ Specimens collected by Krauss in October 1952 (Lieftinck 1962).

${ }^{c}$ Collected by T. Esaki, 24 January 1938 (Asahina 1940).

${ }^{d}$ Specimen(s) collected by Bates during July-August 1953 (Lieftinck 1962).

e Specimen collected by Nelson Tafilelyango during July-August 2005 and brought to D.W.B.

$f$ Known in Yap only from a single male collected by R. J. Goss during July-August 1950.

$g$ Including 28 listed under Neurothemis terminata terminata and six identified as Neurothemis sp.

${ }^{b}$ One specimen in the Bishop Museum collection examined by D.W.B.; see also Lieftinck (1962:79).

${ }^{i}$ Reported from Micronesia for the first time, but an old record of O. sabina from Tobi, Southwest Palau Islands, possibly pertains to $O$. serapia.

${ }^{j}$ Known in Micronesia only from a single male collected in Yap by R. J. Goss during July-August 1950.

of any mention of these two unusual records by Lieftinck (1962) is perplexing but no more so than his omission of Yap from the list of Micronesian localities where Anax guttatus has been recorded, especially in view of an early instar larva in the Bishop Museum identified as an A. guttatus from Yap determined by Lieftinck in 1952 .

YAP OUTER ISLANDS: Odonata have not been systematically surveyed on any of the 15 island groups that make up the outer islands of Yap State. Only six species have been recorded from among four island groups and with no more than four species from any one group (Table 1). Many of these records were reported by Lieftinck (1962) under the heading "Caroline Atolls." Five of the six species are widely distributed throughout the Caroline Islands on low-lying atoll islets as well as on the main, high islands. The only exception is Neurothemis terminata, which apparently ranges only as far east as Fais Island, Yap State (Lieftinck 1962), but see remarks on an unusual specimen record from Kosrae earlier in the Discussion. Clearly, additional fieldwork is needed for a more complete understanding of the biogeography of Odonata in this part of the $\mathrm{Pa}$ cific, but the remote location of these islands and lack of reliable local transportation remain obstacles to biologists who would visit.

\section{ACKNOWLEDGMENTS}

We thank Katsuo Tsuda for the unpublished list of Odonata collected by the Kagoshima University Expedition to Yap and Ulithi, and Nelson Tafilelyango for his recently collected 
specimens from Ifalik Atoll. We thank Kazunobu Kano and Kiyoshi Inoue for sending us photos of Orthetrum sabina from Guam. We also thank Al Samuelson and Ron Englund for access to collections in the Bishop $\mathrm{Mu}$ seum and we are grateful to the library staff at the College of Micronesia, Micronesia Seminar, Museum of Comparative Zoology (Harvard University), University of Guam, and University of Hawai'i for their assistance in obtaining pertinent literature.

\section{Literature Cited}

Adams, W. H. 1997. The environment and history of Yap. Pages 1-13 in W. $\mathrm{H}$. Adams, ed. Micronesian resources study: Yap archaeology: Archaeological survey of Gachlaw Village, Gilman Municipality, Yap, Federated States of Micronesia. Micronesian Endowment for Historic Preservation, Federated States of Micronesia, U.S. National Park Service. San Francisco.

Asahina, S. 1940. Odonata-Anisoptera of Micronesia. Tenthredo 3:1-23.

Buden, D. W. 2004. The Odonata of Pakin, Ant, Mokil, and Pingelap Atolls, Eastern Caroline Islands, Micronesia. Micronesica 37:145-155.

Buden, D. W., and D. R. Paulson. 2003. The Odonata of Kosrae, eastern Caroline Islands, Micronesia. Pac. Sci. 57:399407.

. 2004. The Odonata of Chuuk, eastern Caroline Islands, Micronesia. Opusc. Zool. Fluminensia 217:1-11.

Davies, D. A. L., and P. Tobin. 1985. The dragonflies of the world: A systematic list of the extant species of Odonata. Vol. 2. Anisoptera. Societas Internationalis Odonatologica Rapid Communications (Suppl.) 5. Utrecht.

Descantes, C. 2005. Integrating archaeology and ethnohistory: The development of exchange between Yap and Ulithi, western Caroline Islands. British Archaeological Reports International Series 1344. Archaeopress, Oxford.

Dinsmore, C. E., and S. M. Aronson. 1997. In memoriam: Richard J. Goss, 1925-1996. J. Exp. Zool. 277:353-355.
Dodson, J. R., and M. Intoh. 1999. Prehistory and palaeoecology of Yap, Federated States of Micronesia. Quat. Int. 59:17-26.

Falanruw, M. C., C. D. Whitesell, T. G. Cole, C. D. MacLean, and A. H. Ambacher. 1987. Vegetation survey of Yap, Federated States of Micronesia. U.S. Department of Agriculture, Forest Service, Pacific Southwest Forest and Range Experiment Station, Berkeley, California.

Gressitt, J. L. 1954. Insects of Micronesia, introduction. Insects Micronesia 1:1-257.

Inoue, K., K. Kano, H. Kuwahara, O. Sano, and I. Yahiro. 1999. Records of Odonata from Guam Island, Mariana Islands. Sympetrum Hyogo 6:14-22.

Lieftinck, M. A. 1962. Insects of Micronesia, Odonata. Insects Micronesia 5:1-95.

Lobban, C. S. 1989. Freshwater plants of Yap. Pages 37-55 in S. G. Nelson, ed. The inland aquatic habitats of Yap. Univ. Guam Mar. Lab. Tech. Rep. 92.

Merlin, M., A. Kugfas, T. Keene, and J. Juvik. 1996. Plants, people and ecology in Yap. East-West Center, Honolulu, Hawai $i$.

Mueller-Dombois, D., and F. R. Fosberg. 1998. Vegetation of tropical Pacific islands. Springer-Verlag, New York.

Munetomo, N., M. Tomokazu, S. Ryoichi, I. Akio, S. Kiyoshi, H. Masataka, H. Akimasa, A. Takafumi, and H. Akio. 2001. Geological environments of Yap Islands, Micronesia. Kagoshima University Research Center for the Pacific Islands Occas. Pap. 34:69-76.

Paulson, D. R. 2003. Teinobasis budeni sp. nov. from Pohnpei, eastern Caroline Islands Micronesia (Odonata: Coenagrionidae). Int. J. Odonatol. 6:33-37.

Paulson, D. R., and D. W. Buden. 2003. The Odonata of Pohnpei, eastern Caroline Islands, Micronesia. Int. J. Odonatol. 6:3964.

Rowe, R. J. 2004. Conservation of Odonata in the South Pacific and Australia. Int. J. Odonatol. 7:139-147.

Schreiner, I., and D. Nafus. 1989. Insects in the freshwater environments of Yap. Pages 21-32 in S. G. Nelson, ed. The inland aquatic habitats of Yap. Univ. Guam Mar. Lab. Tech. Rep. 92. 
Steinmann, H. 1997. World catalogue of Odonata. Vols. 1 and 2. Walter de Gruyer, New York.

Tsuda, K., M. Watanabe, S. Tominaga, M. Onjo, and K. Ichitani. 2003. The biogeography of the insect fauna of Ulithi Islands, Micronesia. Kagoshima University Research Center for the Pacific Islands Occas. Pap. 39:73-75.

van der Brug, O. 1983. Water resources of the Yap Islands. U.S. Geological Survey Water-Resources Investigations Rep. 82357. U.S. Geological Survey, Honolulu.

Watson, J. A. L. 1984. A second Australian species in the Orthetrum sabina complex (Odonata: Libellulidae). J. Aust. Entomol. Soc. 23:1-10.

Watson, J. A. L., G. Theischinger, and H. M. Abbey. 1991. The Australian dragonflies. CSIRO, Canberra and Melbourne. 
